\title{
KOMPARASI PARENTING SELF-EFFICACY PADA IBU USIA REMAJA DAN DEWASA DI KECAMATAN BANJARHARJO BREBES
}

\author{
Nurul Fajriyah ${ }^{1}$, Laila Qodariah ${ }^{2}$, Marisa Fransiska M. ${ }^{3}$ \\ ${ }^{1,2,3)}$ Fakultas Psikologi, Universitas Padjadjaran \\ Jl. Raya Bandung-Sumedang KM. 21 Jatinangor, Sumedang \\ Email: nurul14001@mail.unpad.ac.id
}

Diserahkan 11 Desember 2018; Diterima 19 Maret 2019; Dipublikasikan 01 April 2019

\begin{abstract}
ABSTRAK
Sepanjang tahun 2017, fenomena pernikahan usia dini di Kabupaten Brebes terjadi paling tinggi di Jawa Tengah, terutama di Kecamatan Banjarharjo. Tingginya angka pernikahan usia dini ini membuat remaja perempuan di Kecamatan Banjarharjo memiliki kesempatan yang lebih besar pula untuk menjadi seorang ibu di usia remaja. Akan tetapi, ibu usia remaja dianggap masih kurang kompeten secara kognitif dalam hal mengambil peran orang tua, pengetahuan tentang tahap perkembangan bayi, dan cenderung lebih menonjolkan sifat keremajaannya daripada sifat keibuannya, bila dibandingkan dengan para ibu yang telah dewasa secara psikologis yang akan lebih terkendali emosi maupun tindakannya. Tujuan dari penelitian ini adalah untuk mengetahui perbandingan gambaran parenting self-efficacy pada ibu usia remaja dan dewasa di Kecamatan Bajarharjo Kabupaten Brebes. Penelitian ini dilakukan pada 107 orang yang terdiri dari 53 orang ibu usia remaja dan 54 orang dewasa di Kecamatan Banjarharjo. Metode penelitian yang digunakan adalah studi komparatif, responden diminta mengisi kuesioner SEPTI-TS. Reliabilitas alat ukur Self Efficacy for Parenting Tasks Index-Toddler Scale (SEPTI-TS) adalah sebesar 0,881. Hasil penelitian ini adalah tidak terdapat perbedaan tingkat parenting self-efficacy yang signifikan antara ibu usia remaja dan dewasa di Kecamatan Banjarharjo. Meskipun memiliki tingkat parenting self-efficacy tinggi, ibu usia remaja masih banyak yang merasa kurang mampu untuk mengerti ketika perasaan anak tersakiti dan memberikan kenyamanan bagi anaknya ketika anak membutuhkan mereka ketika frustasi atau takut, dibandingkan dengan ibu usia dewasa.
\end{abstract}

Kata kunci: ibu usia dewasa, ibu usia remaja, parenting self-efficacy, pernikahan usia dini.

\section{COMPARATIVE STUDY OF PARENTING SELF-EFFICACY OF ADOLESCENT MOTHER AND ADULT MOTHER IN BANJARHARJO BREBES}

\begin{abstract}
Throughout the year 2017, the phenomenon of early marriage in Brebes District became the highest in Central Java, especially in the Subdistrict of Banjarharjo. The high number of early marriages would certainly make teenage girls in the Sub-district of Banjarharjo have a greater opportunity to become a mother in adolescence. Teenage mothers were considered to be less competent cognitively in terms of taking the role of parents, knowledge of developmental stages their infant, and tended to highlight her youthfulness rather than her maternal nature when compared to psychologically mature mothers who would be more emotionally controlled as well her actions. The purpose of this research was to find out the comparison of parenting self-efficacy in adolescent mothers and mature mothers in Bajarharjo Sub-district. This study was conducted on 107 people consisting of 53 adolescent mothers and 54 mature mothers in Banjarharjo Sub-district. The research method was comparative study, participants were asked to fill out the Self Efficacy for Parenting Tasks Index-Toddler Scale (SEPTI-TS) questionnaire. Reliability of SEPTI-TS measuring instrument was 0.881. The results of this study were: there was no significant differences in parenting self-efficacy between adolescent mothers and adult mothers in Banjarharjo Subdistrict. However, despite having a high parenting self-efficacy level, many teenage mothers still feel that they were unable to understand when was their child feelings are hurt and to provide comfort for their children at the same time when children need them when frustrated or afraid, compared to adults.
\end{abstract}

Keywords: adult mother, adolescent mother, parentingself-efficacy, early marriage. 


\section{PENDAHULUAN}

Menikah atau mempersiapkan diri untuk menikah merupakan salah satu tugas perkembangan masa remaja akhir atau dewasa awal, yaitu pada usia antara 18-22 tahun (Adhim, M. Z., 2002). Papalia dan Olds (2009) mengemukakan, usia menikah terbaik atau ideal adalah pada usia 19-25 tahun bagi perempuan, sedangkan bagi laki-laki usia terbaik untuk menikah adalah 20-25 tahun. Usia tersebut merupakan usia terbaik untuk menikah, serta untuk memulai kehidupan rumah tangga maupun untuk mengasuh anak pertama. Hal ini dikarenakan pada usia tersebut individu dianggap telah matang secara emosional maupun fisik.

Menurut World Health Organization (WHO) (dalam McIntyre, 2006), pernikahan yang dilakukan oleh pasangan berusia dibawah 19 tahun merupakan pernikahan dini (early marriage). Sedangkan menurut International Planned Parenthood Federation (2007), pernikahan anak didefinisikan sebagai pernikahan yang terjadi sebelum anak mencapai usia 18 tahun, sebelum anak matang secara fisiologis dan psikologis untuk bertanggungjawab terhadap pernikahan dan anak yang dihasilkan dari pernikahan tersebut.

Indonesia sendiri termasuk negara dengan persentase pernikahan usia dini tinggi di dunia (peringkat 37) dan tertinggi ke dua di ASEAN setelah Kamboja. Pada tahun 2010, terdapat 158 negara dengan usia legal minimum menikah adalah 18 tahun ke atas, dan Indonesia masih diluar itu (BKKBN, 2012). Berdasarkan data dari Badan Pusat Statistik (2017), tercatat bahwa prevalensi pernikahan usia anak di Indonesia pada tahun 2013 adalah sebesar 24\%. Kemudian pada tahun 2015, prevalensi pernikahan usia anak di Indonesia hanya mengalami penurunan sekitar $1 \%$ yaitu menjadi $23 \%$ yang artinya satu dari lima perempuan pernah menikah usia 20-24 tahun melakukan pernikahan pertama sebelum usia 18 tahun.

Berkaitan dengan fenomena pernikahan usia dini, Kabupaten Brebes merupakan salah satu daerah di Indonesia yang memiliki angka pernikahan usia dini tinggi. Sepanjang tahun 2017, Kabupaten Brebes menempati posisi pertama pernikahan anak usia dini tertinggi se-Provinsi Jawa Tengah (Okezone News, 2017). Berdasarkan data yang diperoleh dari Kantor Kementerian Agama (KANKEMENAG) Kabupaten Brebes, tercatat bahwa jumlah perempuan yang menikah dibawah usia produktif ( $<20$ tahun) di Kabupaten Brebes sepanjang tahun 2017 adalah sebanyak 4.135 orang. Sedangkan Kecamatan Banjarharjo merupakan salah satu kecamatan di Kabupaten Brebes dengan jumlah persentase pernikahan usia dini ( $<20$ tahun) paling tinggi sepanjang tahun 2017, yaitu sebesar $37 \%$ dari total jumlah pernikahan di Kecamatan Banjarharjo atau sebanyak 458 orang yang seluruhnya berjenis kelamin perempuan.

Tingginya angka pernikahan usia remaja ini tentunya akan membuat remaja perempuan di Kecamatan Banjarharjo memiliki kesempatan yang lebih besar pula untuk menjadi seorang ibu di usia yang masih remaja. Sedangkan salah satu tugas individu ketika telah menjadi orang tua adalah mengasuh anak atau proses pengasuhan; dan tugas tersebut umumnya dilakukan oleh seorang ibu (Bernard dan Parke, n.d;dalam Bornstein, 2002). Namun, pernikahan yang dilakukan di usia remaja ini umumnya akan menimbulkan beberapa dampak negatif atau masalah, yaitu bagi perkembangan anak yang dilahirkan maupun kondisi kesehatan psikologis ibu (Crugnola, et al., 2014).

Dampak yang ditimbulkan dari pernikahan usia dini ini dianggap karena ibu yang berusia dibawah 20 tahun masih kurang kompeten secara kognitif dalam hal mengambil peran orang tua (kesiapan kognitif untuk orang tua) dan pengetahuan tentang tahap perkembangan bayi mereka (Crugnola, et al., 2014). Selain itu, ibu usia remaja juga cenderung lebih menonjolkan sifat keremajaannya daripada sifat keibuannya, bila dibandingkan dengan para ibu yang telah dewasa secara psikologis yang akan lebih terkendali emosi maupun tindakannya (Purnawati, 2015).

Berkaitan dengan kondisi emosional remaja, Santrock (2010) mengemukakan bahwa perkembangan prefrontal cortex (bagian frontal lobe) yang berfungsi sebagai pusat penalaran, mengambil keputusan, dan kontrol diri belum matang pada usia remaja hingga individu berusia 18-25 tahun. Sedangkan amygdala atau bagian pusat emosi justru yang matang lebih cepat pada remaja. Pada kondisi ini remaja memiliki emosi yang kuat, namun prefrontal cortex remaja belum berkembang sampai pada titik di mana mereka dapat mengendalikan emosi mereka. Sehingga hal ini membuat otak remaja seolah-olah tidak memiliki rem untuk memperlambat emosi remaja (Dahl, 2004; dalam Santrock, 2010).

Kondisi emosional ini sendiri nantinya dapat mempengaruhi ibu dalam mengasuh anak. Bukti pentingnya kesejahteraan emosional orang tua dalam pengasuhan telah ada dari berbagai sumber (Dix, 1991; dalam Adam, 2004). Studi mengenai orang tua yang menampilkan emosi negatif telah mengungkapkan berbagai konsekuensi perilaku negatif, seperti orang tua lebih sedikit menampilkan ekspresi wajah positif; kurang hangat, sensitif, dan memberikan afeksi (Downey \& Coyne, 1990; Field, 1995; Lovejoy et al., 2000; Teti et al., 1995; dalam Adam, 2004). Sedangkan emosi positif orang tua berkaitan dengan pengasuhan yang bersifat hangat dan mendukung (Mangelsdorf, Gunnar, Kestenbaum, Lang, \& Andreas, 1990; dalam Adam, 2004).

Ketidakmatangan perkembangan kognitif dan neurofisiologis pada ibu usia remaja ini mungkin menjadi hambatan bagi ibu dalam mengambil peran orang tua (kesiapan kognitif untuk orang tua) dan pengetahuan tentang tahap perkembangan bayi mereka (Crugnola, et al., 2014). Sehingga membuat ibu usia remaja cenderung menunjukkan perilaku pengasuhan yang kurang responsif dan sensitif, menggunakan lebih 
sedikit vokalisasi, dan memberikan lingkungan yang kurang merangsang untuk bayi mereka daripada ibu dewasa (Mercer, 1995; dalam DeVito, 2007).

Menurut Ragozin, et al. (1982; dalam Papalia, Old, dan Fieldman, 2009), individu yang menikah dan memiliki anak di usia produktif merasa lebih puas dengan kegiatan mengasuh anak dan menghabiskan lebih banyak waktu untuk melakukannya. Mereka juga lebih sayang dan peka terhadap bayi mereka, serta lebih efektif dalam mendorong perilaku yang diinginkan anaknya. Orang tua dewasa juga lebih sedikit dalam memberikan hukuman, baik dalam bentuk verbal maupun fisik bila dibandingkan dengan ibu usia remaja. Anak yang dilahirkan oleh ibu dewasa juga menunjukkan lebih sedikit permasalahan perilaku, sosial dan emosional (Trillingsgaard, T \& Sommer, D, 2016).

Menjadi orang tua di usia remaja disertai keterampilan yang kurang untuk mengasuh anak sebagaimana yang dimiliki orang dewasa dapat menempatkan anak yang dilahirkan berisiko mengalami perlakuan salah dan/atau penelantaran (Fadlyana \& Larasaty, 2009). Kurangnya kesiapan dan keterampilan untuk mengasuh anak pada ibu usia remaja ini nantinya dapat mempengaruhi bagaimana ibu mempersepsikan kemampuannya dalam proses pengasuhan. Hal ini karena salah satu faktor yang dapat mempengaruhi tingkat parenting self-efficacy ibu adalah kesiapan menjadi orang tua dalam hal kognitif maupun perilaku (Coleman \& Karraker, 2000). Adapun kesiapan kognitif maupun perilaku yang dimaksud yaitu, pengetahuan ibu akan tugas sebagai orang tua, tahapan perkembangan bayi, pemilihan metode pengasuhan, pengetahuan umum yang akan menjadi bekal dalam mengajari anak-anaknya, dan sebagainya (Leen \& Karraker, 2002; dalam Saracho \& Sapodek, 2005).

Menurut Coleman dan Karraker (2000), parenting self efficacy merupakan estimasi atau persepsi orang tua akan kemampuan mereka untuk secara positif mempengaruhi perilaku dan perkembangan anak-anak mereka. Coleman dan Karraker (2003) sendiri mengemukakan bahwa parenting self-efficacy ini dapat diukur melalui persepsi orang tua terhadap kompetensinya dalam melakukan tujuh aspek atau dimensi dari parenting self-efficacy, yaitu:

1. Emotional availability:persepsi orang tua terhadap kemampuannya untuk selalu ada jika anaknya membuatuhkannya.

2. Nurturance:persepsi orang tua dalam memahami mood anaknya dan memberikan respons yang tepat.

3. Protection from harm and injury:persepsi orang tua terhadap kemapuannya untuk melindungi anaknya dari bahaya.

4. Discipline and limit setting:persepsi orang tua terhadap kemampuannya dalam memberikan aturan-aturan dan disiplin kepada anaknya.

5. Playing: persepsi orang tua terhadap kemampuannya bermain dengan anaknya.
6. Teaching:persepsi orang tua terhadap kemampuannya dalam mengajarkan anaknya mengenai konsep-konsep mengenai dunia.

7. Instrumental care and establishment of structure and routines:persepsi orang tua terhadap kemampuannya dalam menyusun jadwal rutin untuk anaknya.

Selain itu, Coleman dan Karraker (2000) juga mengemukakan bahwa tingkat parenting selfefficacyini dapat dipengaruhi oleh beberapa faktor, diantaranya yaitu:

1. Pengalaman masa kecil orang tua

2. Budaya dan komunitas setempat

3. Pengalaman orang tua dengan anak-anak

4. Tingkat kesiapan menjadi orang tua dalam segi kognitif maupun perilaku

5. Dukungan sociomarital

6. Karakteristik anak

Peneliti sendiri belum berhasil menemukan penelitian sebelumnya yang meneliti gambaran parenting self-efficacy pada ibu usia remaja. Peneliti hanya menemukan gambaran proses pengasuhan pada ibu usia remaja. Oleh karenaitu, upaya lebih lanjut peneliti untuk mengetahui gambaran permasalahan mengenai parenting self-efficacy berdasarkan aspekaspekparenting self-efficacy pada ibu usia remaja di Kecamatan Banjarharjo, yaitu dengan mewawancarai 7 orang ibu usia remaja (17 dan 18 tahun) dan 5 orang ibu usia dewasa (25-28 tahun) yang memiliki anak pertama berusia balita (2-3 tahun) di Kecamatan Banjarharjo.

Berdasarkan hasil wawancara, didapatkan bahwa hasil data awal tersebut sesuai dengan teori yang menunjukkan bahwa ibu usia dewasa lebih kompeten dalam mengasuh anak. Ibu usia dewasa hampir seluruhya tidak mengalami permasalahan atau kesulitan dalam melakukan hal yang berkaitan dengan parenting self-efficacy, seperti memahami mood anak, bermain dengan anak, menetapkan aturan, mengajarkan sesuatu hal, dan membuat jadwal kegiatan rutin bagi anaknya, bila dibandingkan dengan beberapa ibu usia remaja yang yang sebagian besar menunjukkan bahwa mereka masih mengalami kesulitan dan kebingungan dalam melakukan hal-hal yang berkaitan dengan parenting self-efficacy.

Meskipun demikian, berdasarkan data awal juga didapatkan hasil bahwa beberapa ibu usia remaja lainnya menujukkan bahwa mereka tidak mengalami permasalahan atau kesulitan dalam melakukan hal-hal yang berkaitan dengan parenting self-efficacy. Hal ini tidak sesuai dengan teoriyang mengatakan bahwa ibu usia remaja masih kurang kompeten dalam merawat anak bila dibandingkan dengan ibu dewasa. Oleh karena itu, hal ini membuat peneliti ingin mengetahui apakah terdapat perbedaan tingkat parenting selfefficacy pada ibu usia remaja dan dewasa di Kecamatan Banjarharjo Kabupaten Brebes.

Namun berdasarkan data awal, jumlah ibu usia remaja yang merasa masih mengalami kesulitan dan kebingungan dalam melakukan hal-hal yang berkaitan dengan parenting self-efficacy lebih banyak bila 
dibandingkan jumlah ibu usia remaja yang menunjukkan bahwa mereka tidak mengalami permasalahan atau kesulitan dalam melakukan hal-hal yang berkaitan dengan parenting self-efficacy. Sehingga penelitimembuat hipotesis bahwa terdapat perbedaan tingkat parenting self-efficacy pada ibu usia remaja dan dewasa di Kecamatan Bajarharjo.

\section{METODE}

Penelitian ini merupakan penelitian kuantitatif non eksperimental dengan metode komparasi (Nazir, M., 2005). Populasi dari penelitian ini adalah ibu yang menjadi orang tua di usia remaja yang berusia 15-18 tahun dan ibu usia dewasa, yaitu yang berusia diatas 25 tahun di Kecamatan Banjarharjo Kabupaten Brebes yang memiliki anak balita berusia 2-3 tahun. Karakteristik sampel penelitian ini antara lain berdomisili di Kecamatan Banjarharjo, berjenis kelamin perempuan, berusia 15-18 tahun bagi ibu usia remaja, berusia diatas 20 tahun bagi ibu usia dewasa, dan memiliki anak pertama berusia 2-3 tahun.

Teknik sampling yang digunakan dalam penelitian ini adalah teknik non-probability sampling yaitu snowball sampling.Pada proses pengambilan data, peneliti mencari partisipan yang sesuai dengan kriteria, kemudian meminta alamat partisipan potensial lainnya pada partisipan sebelumnya. Peneliti kemudian mendatangi rumah partisipan yang sesuai dengan kriteria penelitian satu-persatu. Selain itu, peneliti juga dibantu oleh pihak Kantor Urusan Agama (KUA) atau perangkat desa setempat untuk mendatangi alamat partisipan yang sesuai dengan kriteria. Selama proses pengambilan data, peneliti memperoleh sampel sebanyak 6-8 orang setiap harinya dan pengambilan data penelitian ini dilakukan hampir setiap hari selama satu bulan.Berdasarkan metode yang dilakukan oleh peneliti, didapatkan jumlah sampel sebanyak 107 orang yang terdiri dari 53 orang ibu usia remaja dan 54 orang ibu usia remaja.

Pengukuran variabel parenting self-efficacy dalam penelitian ini menggunakan alat ukur berbentuk kuesioner untuk melihat parenting self-efficacy pada ibu yang memiliki anak dengan usia toddler, yaitu The Self-Efficacy for Parenting Task Index - Toddler Scale (SEPTI-TS) dari Coleman \& Karraker (2003). Alat ukur ini telah diadaptasi dalam bahasa Indonesia oleh Dra. Erniza Miranda Madjid, M.Si., dan kolega pada penelitian payung Fakultas Psikologi Universitas Indonesia terkait parenting self-efficacy pada tahun 2012. Reliabilitas alat ukur ini dalam penelitian sebelumnya yang dilakukan oleh Ranindra, A (2014) adalah sebesar 0,883. Alat ukur ini terdiri dari 53 item yang terbagi dalam tujuh dimensi, yaitu
1. emotional availability
2. nurturance,
3. protection
4. discipline,
5. play,
6. teaching, dan

\section{7. instrumental care}

Pilihan jawaban untuk setiap item menggunakan skala Likert 6 poin, yaitu dengan pilihan jawaban 'sangat tidak setuju' memiliki skor 1 dan pilihan jawaban 'sangat setuju' memiliki skor 6 .

Pada penelitian ini, peneliti membuat kategorisasi alat ukur berdasarkan kategorisasi dari Coleman dan Karraker (2003) pada alat ukur SPETITS. Skor total parenting self-efficacy darialatukur SEPTI-TS ini dikategorikan menjadi dua kategori, yaitu tinggi dan rendah. Kategori ini didapatkan dengan menghitung skor tertinggi dari parenting selfefficacy dikurang skor terendah dari parenting selfefficacy, hasil dari selisih skor akan dibagi dua dan ditambahkan ke skor terendah untuk menjadi kategori rendah.

\section{Tabel.1 KategoriParenting Self-Efficacy}

Kategorisasi yang digunakan dalam penelitian ini adalah sebagai berikut:

\begin{tabular}{ll}
\hline Kategorisasi & Skor \\
\hline Rendah & $53-185.5$ \\
Tinggi & $185.6-318$ \\
\hline
\end{tabular}

Metode pengolahan data dalam penelitian ini dikalakukan dengan menggunakan IBM SPSS Statistics 21 yaitu, statistika deskriptifuntuk melihat gambaran umum dari subyek penelitiandan uji mann-whitney untuk melihat perbedaan tingkat parenting self-efficacy antara ibu usia remaja dan dewasa.Peneliti juga menggunakan alat ukur tambahan untuk memperoleh data penunjang. Alat ukur ini berupa pertanyaan wawancara yang disusun oleh peneliti berdasarkan aspek-aspek yang berkaitan dengan pernikahan usia dini, faktor-faktor parenting self-efficacy, dan peranan parenting self-efficacy.

Selain melakukan analisis pada setiap dimensi, peneliti juga melakukan analisis pada setiap item dengan menggunakan modus. Hasil dari analisis tiap item dapat dilihat pada lampiran. Analisis tiap item ini memberikan gambaran data kondisi parenting selfefficacy ibu usia remaja dan dewasa berdasarkan setiap item. Hasil dari analisis tiap item ini akan peneliti gunakan sebagai data penjelas dalam pembahasan.

\section{HASIL DAN PEMBAHASAN}

Berdasarkan hasil perhitungan dengan menggunakan IBM SPSS Statistics 21 didapatkan hasil sebagai berikut:

Tabel2. Hasil Uji Beda Parenting Self-Efficacy Ibu Usia Remaja dan Dewasa

\begin{tabular}{cccc}
\hline Usia Ibu & N & Rata-rata & p-value \\
\hline Remaja & 53 & 54.48 & 0,874 \\
Dewasa & 54 & 53.53 & \\
\hline
\end{tabular}


Berdasarkan Tabel 2, dapat dilihat bahwa $p$ value $(0,874)>\alpha(0.05)$ yang artinya $\mathrm{H}_{0}$ diterima. Hal tersebut menunjukkan bahwa tidak terdapat perbedaan tingkat parenting self-efficacy yang signifikan antara ibu usia remaja dan dewasa di Kecamatan Banjarharjo Kabupaten Brebes.

Tabel3. Hasil Uji Beda Dimensi Parenting SelfEfficacy Ibu Usia Remaja dan Dewasa

\begin{tabular}{|c|c|c|c|}
\hline \multirow[t]{2}{*}{ Dimensi } & \multicolumn{2}{|c|}{ Jumlah } & \multirow{2}{*}{ Value } \\
\hline & Remaja & Dewasa & \\
\hline Emotional Availability & 51.27 & 56.68 & 0.366 \\
\hline Nurturance & 50.89 & 57.06 & 0.300 \\
\hline $\begin{array}{l}\text { Protection from harm } \\
\text { and injury }\end{array}$ & 54.05 & 53.95 & 0.988 \\
\hline $\begin{array}{l}\text { Dicipline and limit } \\
\text { setting }\end{array}$ & 51.50 & 56.45 & 0.407 \\
\hline Playing & 56.08 & 51.95 & 0.489 \\
\hline Teaching & 56.19 & 51.85 & 0.460 \\
\hline Instrumental care & 54.92 & 53.10 & 0.762 \\
\hline
\end{tabular}

Berdasarkan Tabel 3, dapat dilihat bahwa $p$ valuedari masing-masing dimensi memiliki nilai lebih besar dari $(>) \alpha(0.05)$ yang artinya $\mathrm{H}_{0}$ dari seluruh dimensi PSE diterima. Hal tersebut menunjukkan bahwa tidak terdapat perbedaan tingkat parenting selfefficacy(PSE) yang signifikan pada masing-masing dimensi PSE antara ibu usia remaja dan dewasa di Kecamatan Banjarharjo Kabupaten Brebes.

Tabel4. GambaranKategoriParenting Self-Efficacy IbuUsiaRemaja dan Dewasa

\begin{tabular}{llcc}
\hline \multirow{2}{*}{ Kategori } & \multirow{2}{*}{ Skor total } & \multicolumn{2}{c}{ Jumlah } \\
\cline { 3 - 4 } & & Remaja & Dewasa \\
\hline Rendah & $53-185.5$ & $9(8.41 \%)$ & $10(9.35 \%)$ \\
\hline Tinggi & $185.6-318$ & $44(41.12 \%)$ & $44(41.12 \%)$ \\
\hline
\end{tabular}

Selanjutnya pada Tabel 4 ini dapat dilihat bahwa ibu usia remaja yang memiliki tingkat parenting self-efficacy yang tinggi yaitu sebanyak 44 orang $(41.12 \%)$ dan 9 orang $(8.41 \%)$ memiliki tingkat parenting self-efficacy yang rendah. Sedangkan ibu usia dewasa sebanyak 44 orang (41.12\%) memiliki tingkat parenting self-efficacy yang tinggi dan sebanyak $10(9.35 \%)$ memiliki tingkat parenting selfefficacy yang rendah. Hal ini menunjukkan bahwa pada penelitian ini lebih banyak ibu usia remaja maupun dewasa yang memiliki tingkat parenting self-efficacy yang tinggi.

Ibu yang memiliki tingkat parenting selfefficacy tinggi menunjukkan bahwa dalam proses pengasuhan, ibu memiliki perilaku parenting yang positif dengan lingkungan pengasuhan yang sehat dan menyenangkan, lebih banyak terlibat secara penuh dalam menjalankan perannya sebagai orang tua, serta responsif terhadap kebutuhan anak. Namun, tingginya tingkat parenting self-efficacy pada ibu usia remaja ini tidak sesuai dengan apa yang dikemukakan oleh Crugnola, et al. (2014). Ia mengemukakan bahwa ibu di bawah usia 20 tahun masih kurang kompeten secara kognitif dalam hal mengambil peran orang tua (kesiapan kognitif untuk orang tua) dan pengetahuan tentang tahap perkembangan bayi mereka. Sedangkan menurut Coleman dan Karraker (2000), salah satu faktor yang dapat mempengaruhi parenting selfefficacy adalah kesiapan menjadi orang tua dalam hal kognitif maupun perilaku.

Meskipun demikian, berdasarkan data penunjang didapatkan hasil bahwa sebanyak 49 orang ibu usia remaja menyiapkan diri mereka sebelum memutuskan untuk menikah dan sebanyak 4 orang ibu usia remaja tidak menyiapkan diri mereka. Sedangkan ibu usia dewasa seluruhnya menyatakan bahwa mereka menyiapkan diri mereka sebelum memutuskan untuk menikah. Baik ibu usia remaja dan dewasa yang menyiapkan diri sebelum menikah menuturkan bahwa mereka mencari informasi melalui media online, mendapat informasi dari keluarga, dan dari tetangga atau teman mereka. Ibu yang menyiapkan diri sebelum menikah menuturkan bahwa mereka merasa lebih mudah ketika merawat anak. Sedangkan ibu usia remaja yang tidak menyiapkan diri sebelum menikah, sebanyak tiga orang menuturkan bahwa mereka merasa kesulitan dalam merawat anak dan satu orang lainnya merasa biasa saja. Hal tersebut menunjukkan bahwa ibu usia remaja dan dewasa di Kecamatan Banjarharjo yang menjadi responden dalam penelitian ini hampir seluruhnya telah mempersiapkan diri mereka sebelum memutuskan untuk menikah.

Selain itu, jika dilihat berdasarkan faktor-faktor parenting self-efficacy yang lainnya, ibu usia remaja maupun dewasa dalam penelitian ini menuturkan bahwa mereka menerapkan pengalaman masa kecil saat merawat dan mengasuh anak mereka; mengikuti budaya atau mitos setempat, saat merawat dan mengasuh anak, seperti seperti membawa anak ke dukun jika sedang sakit dan anak tidak boleh keluar saat maghrib; memiliki pengalaman dengan anak-anak, seperti mengasuh adik, sepupu, maupun bekerja menjadi pengasuh anak; mendapatkan dukungan dan bantuan dari suami, orang tua, sanak saudara, bahkan tetangga; dan ibu juga tidak menganggap bahwa perilaku yang muncul dari anak merupakan suatu masalah bagi mereka saat merawat anak.

Berdasarkan hasil dari data penunjang tersebut menunjukkan bahwa hampir seluruh ibu usia remaja maupun dewasa di Kecamatan Banjarharjo yang menjadi responden dalam penelitian ini telah melakukan beberapa hal yang merupakan faktor-faktor yang dapat mempengaruhi tingkat parenting selfefficacy menurut Coleman dan Karraker (2000).

Parenting self-efficacy ini sendiri terdiri dari 7 aspek, yaitu emotional availability, nurturance, protection from harm and injury, dicipline and limit setting, playing, teaching, dan instrumental care. Berdasarkan hasil sebelumnya menunjukkan bahwa tingkat parenting self-efficacy ibu usia remaja dan dewasa yang menjadi responden dalam penelitian ini 
sama-sama berada pada kategori tinggi. Oleh karena itu, peneliti melakukan analisis pada setiap item dalam aspek-aspek parenting self-efficacy untuk melihat apakah terdapat perbedaan antara parenting selfefficacy antara ibu usia remaja dan dewasa yang berada pada kategori tinggi. Analisis pada setiap item ini dilakukan dengan menggunakan modus. Hasil dari analisis tiap item dapat dilihat pada lampiran. Adapun pembahasannya sebagai berkut:

\section{Dimensi Emotional Availability}

Pada dimensi ini, ibu usia remaja maupun dewasa yang memiliki tingkat parenting self-efficacy tinggi merasa bahwa diri mereka mampu untuk selalu ada jika anaknya membutuhkan. Namun, beberapa ibu usia remaja dengan tingkat parenting self-efficacy tinggi merasa masih kurang mampu memberikan kenyamanan bagi anaknya ketika anak membutuhkan mereka di saat frustasi atau takut.

Jika dilihat berdasarkan teori, hal tersebut bisa saja terjadi karena pada saat yang bersamaan ibu usia remaja harus menangani tugas-tugas perkembangan yang berpotensi bertentangan dengan tugas pengasuhan, seperti transisi ke masa dewasa serta menjadi orang tua yang melibatkan mengasuh anak sekaligus merawat kebutuhan fisik dan emosional diri sendiri. Hal ini dapat menimbulkan konflik yang kuat pada ibu muda antara kebutuhannya akan otonomi dan ketergantungan anak yang kuat pada dirinya, sehingga menimbulkan depresi, stress dalam pengasuhan, selfesteem rendah dan juga mempengaruhi cara-cara ibu yang berhubungan dalam merawat anak(Crugnola, et al., 2014).

Perkembangan prefrontal cortex (bagian frontal lobe) yang berfungsi sebagai pusat penalaran, mengambil keputusan, dan kontrol diri belum matang pada usia remaja hingga individu berusia 18-25 tahun. Selain itu, amygdala atau bagian pusat emosi justru yang matang lebih cepat pada remaja. Pada kondisi ini remaja memiliki emosi yang kuat, namun prefrontal cortex remaja belum berkembang sampai pada titik di mana mereka dapat mengendalikan emosi mereka (Santrock, 2010). Kondisi emosional pada remaja nantinya dapat mempengaruhi ibu dalam mengasuh anak, salah satunya yaitu ibu usia remaja menunjukkan perilaku pengasuhan yang kurang responsif dan sensitif (Mercer, 1995; dalam DeVito, 2007).

\section{Dimensi Nurturance}

Pada dimensi ini, ibu usia remaja maupun dewasa yang memiliki tingkat parenting self-efficacy tinggi merasa bahwa diri mereka mampu dalam memahami mood anaknya dan memberikan respon yang tepat. Jika dilihat berdasarkan hasil data penunjang, hal tersebut bisa terjadi karena ibu usia remaja maupun dewasa di Kecamatan Banjarharjo yang menjadi responden penelitian hampir semuanya telah memiliki pengalaman dengan anak kecil sebelum mereka memutuskan menikah. Ibu mengemukakan bahwa pengalaman dengan anak kecil ini sangat membantu mereka ketika telah memiliki anak. Mereka merasa lebih mudah dan mengerti apa yang harus mereka lakukan pada anak. Seperti yang dikemukakan oleh Coleman dan Karraker (2000), bahwa pengalaman ibu dengan anak-anak merupakan salah satu faktor yang mempengaruhi tingkat parenting sefl-efficacy ibu; dan parenting self-efficacy beliefs ini juga berkembang sebagai hasil dari pengalaman yang bersifat langsung (Coleman \& Karraker 1997; dalam Saracho \& Spodek, 2005).

\section{Dimensi Protection FromHarm and Injury}

Pada dimensi ini, ibu usia remaja maupun dewasa yang memiliki tingkat parenting self-efficacy (PSE) tinggi merasa bahwa diri mereka mampu untuk melindungi anaknya dari bahaya. Sedangkan beberapa ibu usia remaja dengan PSE tinggi masih merasa kurang mampu dalam hal menentukan apa yang aman dan tidak aman untuk dilakukan oleh anaknya. Namun, beberapa ibu usia remaja maupun dewasa merasa bahwa diri mereka masih kurang mampu dalam hal menyediakan lingkungan yang aman dan bebas bahaya untuk anak mereka.

Hal tersebut sesuai dengan hasil observasi peneliti saat melakukan pengambilan data. Peneliti melihat bahwa kondisi rumah warga yang terletak di pedesaan dan dengan bangunan yang sederhana, membuat barang-barang tajam atau pecah belah seperti gunting, pisau, piring, gelas, dan lainnya masih bisa dijangkau oleh anak-anak. Selain itu, beberapa ibu juga menuturkan bahwa mereka tidak dapat mengontrol lingkungan mereka yang dapat memberikan dampak buruk bagi anak mereka, seperti kondisi suami, ayah, adik atau tetangga yang merokok.

\section{Dimensi Dicipline and Limit Setting}

Pada dimensiini, jumlah ibu usia dewasa dengan tingkat parenting self-efficacy tinggi yang merasa bahwa diri mereka mampu untuk memberikan aturanaturan disiplin kepada anaknya lebih banyak bila dibandingkan dengan ibu usia remaja. Namun, sebagian ibu usia remaja maupun dewasa merasa bahwa mereka masih kurang mampu dan mengalami kesulitan untuk membuat anak mendengarkan mereka dan mereka juga terkadang merasa putus asa ketika anak mencoba untuk menentang aturan yang telah mereka buat.

Hal tersebut sesuai dengan pernyataan dari Papalia, et al. (2009) yang menyatakan bahwa anak usia balita identik dengan terrible twos, yaitu istilah yang digunakan saat anak sudah mulai mampu menyatakan 'tidak' dan keinginannya sendiri atau memunculkan sikap permusuhan dengan orang tua, tantrum, dan perilaku-perilaku lain yang dilakukan anak hanya untuk mencari tahu apakah anak memiliki cukup kekuatan untuk mendapatkan segala hal yang diinginkannya.

Berdasarkan hasil wawancara, sebagian besar ibu usia remaja dan dewasa sama-sama menuturkan bahwa anak mereka sebenarnya masih kerap menampilkan perilaku-perilaku negatif. Seperti, tantrum karena ingin sesuatu, terkadang tidak 
mendengarkan nasihat orang tua jika suasana hatinya sedang tidak baik. Hal ini mungkin saja menjadi salah satu faktor yang membuat ibu merasa masih kurang mampu dan mengalami sedikit kesulitan untuk membuat anak mendengarkan mereka dan membuat ibu merasa putus asa ketika anak mencoba untuk menentang aturan yang telah mereka buat.

\section{Dimensi Playing}

Ibu usia remaja dan dewasa yang memilliki tingkat parenting self-efficacy tinggi merasa bahwa diri mereka mampu untuk bermain dengan anaknya. Berdasarkan hasil data penunjang, dapat dilihat bahwa hampir seluruh ibu usia remaja maupun dewasa yang menjadi responden telah memiliki pengalaman sebelumnya dengan anak-anak. Biasanya mereka ikut merawat adik, keponakan, sepupu, atau kerja menjadi pengasuh anak sebelum mereka menikah.

Pengalaman tersebut mungkin saja menjadi salah satu faktor yang membuat ibu usia remaja maupun dewasa memiliki skor tinggi pada dimensi ini. Selain itu, ibu yang sebelumnya memiliki pengalaman dengan anak-anak juga menuturkan bahwa pengalaman mereka dengan anak-anak ini sangat berpengaruh bagi mereka. Hal tersebut karena dengan adanya pengalaman sebelumnya merawat anak, ibu merasa menjadi lebih mudah ketika merawat anak mereka sendiri. Seperti yang disebutkan oleh Coleman dan Karraker (2000) bahwa pengalaman ibu dengan anakanak merupakan salah satu faktor yang mempengaruhi tingkat parenting sefl-efficacy ibu; dan parenting selfefficacy belief sini juga berkembang sebagai hasil dari pengalaman yang bersifat langsung (Coleman \& Karraker, 1997; dalam Saracho \& Spodek, 2005).

\section{Dimensi Teaching}

Pada dimensi ini, ibu usia remaja maupun dewasa yang memiliki tingkat parenting self-efficacy tinggi merasa bahwa diri mereka mampu untuk mengajarkan anaknya mengenai konsep-konsep dunia. Namun, ibu usia remaja maupun dewasa merasa bahwa mereka masih sedikit kesulitan dalam menentukan instruksi yang jelas dan dapat dimengerti oleh anak.

Berdasarkan data demografi didapatkan hasil bahwa mayoritas ibu usia remaja maupun dewasa berpendidikan SD (sekolah Dasar). Kurangnya pengetahuan umum dan perbendaharaan kosa kata mungkin bisa menjadi salah satu faktor yang membuat ibu merasa sedikit kesulitan dalam menentukan instruksi yang jelas dan dapat dimengerti oleh anak. Seperti yang dikemukakan oleh Yamamato (2001; dalam Holloway, Suzuki, Yamamato, \&Bahrenz, 2005) bahwa semakin tinggi pendidikan yang dimiliki orang tua maka mereka akan semakin yakin dalam hal pengasuhan. Berdasarkan pernyataan tersebut dapat dikatakan bahwa tingkat pendidikan orang tua memiliki pengaruh terhadap tingkat parenting selfefficacy orang tua.

\section{DimensiInstrumental Care}

Pada dimensi ini, ibu usia remaja maupun dewasa yang memiliki tingkat parenting self-efficacy tinggi merasa bahwa diri mereka mampu untuk menyusun jadwal rutin bagi anaknya. Namun,beberapa ibu usia remaja maupun dewasa masih ada yang merasa kurang mampu dalam membuat anak mengikuti jadwal rutin setiap hari. Berdasarkan hasil wawancara, beberapa ibu usia remaja dan dewasa menuturkan bahwa kesulitan ibu dalam menetapkan rutinitas waktu tidur yang teratur bagi anak ini karena biasanya anak mengatakan tidak atau menolak jika diminta untuk tidur malam pada waktu tidur yang seharusnya. Anak lebih memilih untuk bermain atau melakukan kegiatan lainnya.

Sama halnya dengan dimensi discipline, perasaan kurang mampu ibu dalam membuat anak mengikuti jadwal rutin setiap hari pada dimensi instrumental care ini juga mungkin saja di pengaruhi oleh karakteristik anak balita, yaituterrible twos. Pada masa ini anak sudah mulai mampu menyatakan 'tidak' dan keinginannya sendiri atau memunculkan sikap permusuhan dengan orang tua. Sehingga ketika ibu meminta anak untuk tidur atau melakukan sesuatu, anakakanmengatakantidakataumenolakpermintaanibuu ntukmencaritahuapakahanakmemilikicukupkekuatanun tukmendapatkansegalahal yang diinginkannya.

\section{SIMPULAN}

Berdasarkan hasil penelitian ini maka dapat disimpulkan beberapa hal, yaitu tidak terdapat perbedaan tingkat parenting self-efficacy yang signifik antara ibu usia remaja dan dewasa di Kecamatan Banjarharjo, keduanya sama-sama memiliki tingkat parenting self-efficacy yang tinggi. Hal ini menunjukkan bahwa ibu usia remaja maupun dewasa sama-sama memiliki perilaku parenting yang positif dengan lingkungan pengasuhan yang sehat dan menyenangkan, lebih banyak terlibat secara penuh dalam menjalankan perannya sebagai orang tua, serta responsif terhadap kebutuhan anak.

Penelitian ini juga menunjukkan bahwa ibu usia remaja dan dewasa sama-sama telah menerapkan pengalaman masa kecil ketika sedang merawat anak mereka; mengikuti aturan (mitos) yang berlaku di Kecamatan Banjarharjo, seperti membawa anak ke dukun jika sedang sakit dan anak tidak boleh keluar saat maghrib; memiliki pengalaman dengan anak-anak, seperti mengasuh adik, sepupu, maupun bekerja menjadi pengasuh anak; mendapatkan dukungan dan bantuan dari suami, orang tua, sanak saudara, bahkan tetangga; dan ibu juga tidak menganggap bahwa perilaku yang muncul dari anak merupakan suatu masalah bagi mereka saat merawat anak.

Selain itu juga disimpulkan bahwa sebagian besar ibu usia remaja maupun dewasa yang memiliki tingkat parenting self-efficacy tinggi juga merasa bahwa mereka mampu melakukan tugas-tugas pengasuhan yang berkaitan dengan parenting self- 
efficacy. Namun meskipun memiliki tingkat parenting self-efficacy yang tinggi, beberapa ibu usia remaja masih ada yang merasa kurang mampu untuk mengerti ketika perasaan anak tersakiti dan memberikan kenyamanan bagi anaknya ketika anak membutuhkan mereka di saat frustasi atau takut, dibandingkan dengan ibu usia dewasa.

Perasaan kurang mampu ibu usia remaja untuk mengerti ketika perasaan anak tersakiti dan memberikan kenyamanan bagi anaknya ketika anak membutuhkan mereka di saat frustasi atau takut bisa saja terjadi karena pada saat yang bersamaan ibu usia remaja harus menangani tugas-tugas perkembangan yang berpotensi bertentangan dengan tugas pengasuhan. Selain itu, kondisi emosional yang belum stabil akibat perkembangan neurofisiologis belum matang dapat mempengaruhi ibu dalam mengasuh anak, salah satunya yaitu ibu usia remaja menunjukkan perilaku pengasuhan yang kurang responsif dan sensitif.

\section{SARAN}

Penelitian ini masih memiliki kekurangan serta keterbatasan sehingga untuk peneliti selanjutnya dapat mempertimbangakan saran berikut ini:

1. Melakukan penelitian dengan variable dan karakteristik responden yang sama, namun pada daerah lain yang memiliki persentase pernikahan usia remaja tinggi. Hal ini karena pada daerahdaerah tertentu biasanya akan memiliki budaya yang berbeda-beda pula. Sehingga dapat dilihat perbedaannya gambaran parenting self-efficacy ibu usia remaja dan dewasa di Kecamatan Banajrharjo dengan daerah lain berdasarkan faktor budaya daerah setempat.

2. Melakukan penelitian dengan usia responden yang lebih bervariasi dari rentang 15-18 tahun. Hal ini dikarenakan usia responden dalam penelitian ini masih kurang bervariasi.

3. Membuat panduan observasi berkaitan dengan parenting self-efficacy yang nantinya dapat menjadi data penunjang, karena pada saat melakukan pengisian kuesioner, peneliti melakukan observasi kondisi lingkungan namun tidak tertulis.

\section{DAFTAR PUSTAKA}

Adam, K. E., et al. (2004). Adult Attachment, Parent Emotion, and Observed Parenting Behavior: Mediator and Moderator Models. Child Development, 110-122.

Adhim, M. Z. (2002). Indahnya Pernikahan Dini. Jakarta: Gema Insani.

Badan Pusat Statistik. (2017). Perkawinan Usia Anak di Indonesia 2013 dan 2015 Edisi Revisi. Indonesia: Badan Pusat Statistik. Retrieved from

https:/www.bps.go.id/publication/2017/12/25 /b8eb6232361b9d8d990282ed/perkawinanusia-anak-di-indonesia-2013-dan-2015-edisirevisi.html

BKKBN. (2012). Pernikahan Dini Pada Beberapa Provinsi di Indonesia: Dampak Overpopulation, Akar Masalah dan Peran Kelembagaan di Daerah. Retrieved from Badan Kependudukan dan Keluarga Berencana Nasional: https://www.bkkbn.go.id/

Bornstein, M. H. (2002). Handbook of Parenting Vol 3. Being and Becoming A Parent. London: Lawrence Erlbaum Associates, Publisher.

Coleman, P. K. \& Karraker, K. H. (2000). Parenting Self-Efficacy Among Mothers of School-Age Children: Conceptualization, Measurement, and Correlates. Family Relations, 13-24.

Coleman, P. K. \& Karraker, K. K. (2003). Maternal Self-Efficacy Beliefs, Competence in Parenting, and Toddler's Behavior and Developmental Status. Infant Mental, 126148.

Crugnola, et al. (2014). Motherhood in adolescent mothers: Maternal attachment, mother-infant styles of interaction and emotion regulation at three months. Infant Behavior and Development, 44-56.

DeVito, J. (2007). Self-Perceptions of Parenting Among Adolescent Mothers. The Journal of Perinatal Education, 16-23. Retrieved from https://www.ncbi.nlm.nih.gov/pmc/articles/P MC1804313/\#citeref14

Fadlyana, E. \& Larasaty, S. (2009, Agustus ). Pernikahan Usia Dini dan Permasalahannya. Sari Pediatri, Vol. 11, No 2.

IPPF. (2007, November). Ending Child Marriage. Retrieved from International Planned Parenthood Federation: https://www.ippf.org/resource/ending-childmarriage

McIntyre, P. (2006). Marriage Adolescent: on Place of safety. Geneva: WHO Document Production Service.

Nazir, M. (2005). Metode Penelitian. Jakarta: Ghalia Indonesia.

Okezone News. (2017). Kabupaten Brebes Peringkat Pertama Kasus Perkawinan Usia Dini. Retrieved from Okezone News: https://news.okezone.com/read/2017/11/20/51 2/1817465/wow-kabupaten-brebes-peringkatpertama-kasus-perkawinan-usia-dini

Papalia, D. E., Olds, S. W., \& Fieldman, R. D. (2009). Human Development (11th Ed). New York: The McGraw Hill Companies, Inc.

Purnawati, L. (2016). Dampak Perkawinan Muda Terhadap Pola Asuh Keluarga (Studi di desa Talang Kecamatan Sendang Kabupaten Tulungagung). Jurnal Publiciana, http://jurnal- 
Jurnal Psikologi Sains dan Profesi (Journal Psychology of Science and Profession)

Vol. 3, No. 1, April 2019: 12-20

unita.org/index.php/publiciana/article/view/42 . Retrieved from Portalgaruda.

Ranindra, A. (2014). (Skripsi) Parenting Self-efficacy Pada Ibu yang Melakukan Perkawinan Campuran dan Memiliki Anak Toddler. Depok: Universitas Indonesia.

Santrock, J. W. (2010). Child Development, 12th Edition. New York: McGraw-Hill.

Trillingsgaard, T \& Sommer, D. (2016). Associations between older maternal age, use of sanctions, and children's socio-emotional development through 7, 11, and 15 years, European Journal of Developmental Psychology. The European Journal of Developmental Psychology, 141155. 